\title{
The significance of soils and soil science towards realization of the United Nations Sustainable Development Goals
}

\author{
Saskia D. Keesstra ${ }^{1}$, Johan Bouma ${ }^{15, a}$, Jakob Wallinga ${ }^{2}$, Pablo Tittonell ${ }^{3}$, Pete Smith ${ }^{4}$, Artemi Cerdà ${ }^{5}$, \\ Luca Montanarella $^{6}$, John N. Quinton ${ }^{7}$, Yakov Pachepsky ${ }^{8}$, Wim H. van der Putten ${ }^{9,10}$, \\ Richard D. Bardgett ${ }^{11}$, Simon Moolenaar $^{12}$, Gerben Mol $^{13}$, Boris Jansen ${ }^{14}$, and Louise O. Fresco ${ }^{15}$ \\ ${ }^{1}$ Soil Physics and Land Management Group, Wageningen University, Wageningen, the Netherlands \\ ${ }^{2}$ Soil Geography and Landscape Group, Wageningen University, Wageningen, the Netherlands \\ ${ }^{3}$ Natural Resources and Environment Program, Instituto Nacional de \\ Tecnología Agropecuaria (INTA), Bariloche, Argentina \\ ${ }^{4}$ University of Aberdeen, Institute of Biological and Environmental Sciences, Aberdeen, UK \\ ${ }^{5}$ Departament de Geografia, Universitat de València, Blasco Ibàñez, 28, 46010 Valencia, Spain \\ ${ }^{6}$ European Commission, Joint Research Centre, Ispra, Italy \\ ${ }^{7}$ Lancaster University, Lancaster Environment Centre, Lancaster, UK \\ ${ }^{8}$ USDA-ARS, Environmental Microbial and Food Safety Laboratory, Beltsville Agricultural \\ Research Center, Beltsville, MD, USA \\ ${ }^{9}$ Department of Terrestrial Ecology, Netherlands Institute of Ecology NIOO-KNAW, \\ Droevendaalsesteeg 10, 6708 Wageningen, the Netherlands \\ ${ }^{10}$ Department of Nematology, Wageningen University, Droevendaalsesteeg 1, 6708 PB, \\ 6708 Wageningen, the Netherlands \\ ${ }^{11}$ Faculty of Life Sciences, University of Manchester, Oxford Road, Manchester M13 9PT, UK \\ ${ }^{12}$ Commonland, Department of Science \& Education, Amsterdam, the Netherlands \\ ${ }^{13}$ Alterra, Wageningen University and Research Centre, Wageningen, the Netherlands \\ ${ }^{14}$ Institute for Biodiversity and Ecosystem Dynamics (IBED), University of Amsterdam, \\ P.O. Box 94240, 1090 GE Amsterdam, the Netherlands \\ ${ }^{15}$ Wageningen University and Research Centre, Wageningen, the Netherlands \\ ${ }^{a}$ formaly at: Soils Department, Wageningen University, Wageningen, the Netherlands
}

Correspondence to: S. D. Keesstra (saskia.keesstra@wur.nl)

Received: 6 December 2015 - Published in SOIL Discuss.: 18 January 2016

Accepted: 27 March 2016 - Published: 7 April 2016

\begin{abstract}
In this forum paper we discuss how soil scientists can help to reach the recently adopted UN Sustainable Development Goals (SDGs) in the most effective manner. Soil science, as a land-related discipline, has important links to several of the SDGs, which are demonstrated through the functions of soils and the ecosystem services that are linked to those functions (see graphical abstract in the Supplement). We explore and discuss how soil scientists can rise to the challenge both internally, in terms of our procedures and practices, and externally, in terms of our relations with colleague scientists in other disciplines, diverse groups of stakeholders and the policy arena. To meet these goals we recommend the following steps to be taken by the soil science community as a whole: (i) embrace the UN SDGs, as they provide a platform that allows soil science to demonstrate its relevance for realizing a sustainable society by 2030; (ii) show the specific value of soil science: research should explicitly show how using modern soil information can improve the results of inter- and transdisciplinary studies on SDGs related to food security, water scarcity, climate change, biodiversity loss and health threats; (iii) take leadership in overarching system analysis of ecosystems, as soils and soil scientists have an integrated nature and this places
\end{abstract}


soil scientists in a unique position; (iii) raise awareness of soil organic matter as a key attribute of soils to illustrate its importance for soil functions and ecosystem services; (iv) improve the transfer of knowledge through knowledge brokers with a soil background; (v) start at the basis: educational programmes are needed at all levels, starting in primary schools, and emphasizing practical, down-to-earth examples; (vi) facilitate communication with the policy arena by framing research in terms that resonate with politicians in terms of the policy cycle or by considering drivers, pressures and responses affecting impacts of land use change; and finally (vii) all this is only possible if researchers, with soil scientists in the front lines, look over the hedge towards other disciplines, to the world at large and to the policy arena, reaching over to listen first, as a basis for genuine collaboration.

\section{Introduction: what is the challenge?}

In this forum paper we discuss how the soil science profession can address the challenges of the recently adopted UN Sustainable Development Goals in the most effective manner. The sustainability of human societies depends on the wise use of natural resources. Soils contribute to basic human needs like food, clean water, and clean air, and are a major carrier for biodiversity. In the globalized world of the 21 st century, soil sustainability depends not only on management choices by farmers, foresters and land planners but also on political decisions on rules and regulations, marketing and subsidies, while public perceptions are perhaps the most important issue. The United Nations has proposed 17 sustainable development goals, which present a clear challenge to not only national governments but also a wide range of stakeholders. Montanarella and Lobos Alva (2015) provide a historical description of the way in which soils have been discussed in UN documents in recent decades. Their paper demonstrates that, even though soils are essential to sustainable development, they have never been the specific focus of a multilateral environmental agreement (MEA). However, as a crosscutting theme, soils are considered within the three "Rio Conventions" negotiated at the United Nations Conference on Environment and Development (UNCED) in Rio de Janeiro in 1992: (i) the United Nations Framework Convention on Climate Change (UNFCCC), (ii) the United Nations Convention on Biological Diversity (CBD), and (iii) the United Nations Convention to Combat Desertification (UNCCD). As the main binding global environmental agreements, these "Rio Conventions" are considered the framework in which individual countries can implement sustainable development initiatives, aiming at the mitigation of human induced climate change, the protection of biological diversity and the limitation of desertification processes in drylands.

Soils play an important role in each of these issues. Putting soils on the agenda of these MEAs has involved a long process that required a large effort of awareness raising and communication of issues related to the degradation of soils and land by scientists, civil society organizations and policy makers. In spite of these efforts, the convention texts of CBD and UNFCCC do not explicitly discuss the crucial role of soils.
In contrast, soils are addressed in the convention text of the UNCCD, but only restricted to drylands, and in actions prescribed by the three conventions. These actions include the development of national action plans and the definition of specific targets and indicators for the monitoring of natural resources at national level. Twenty years after the conference in Rio, the achievements were analysed at the Rio+20 meeting on sustainable development in 2012 in Rio de Janeiro. This analysis showed that some progress has been made but that extensive land and soil degradation still occurs all over the world and fertile soil resources are still rapidly depleted, reducing the potential for food production. Conscious of these alarming trends, countries participating at the Rio+20 sustainable development conference agreed in the outcome document "The Future We Want" that we should "strive to achieve a land degradation-neutral world in the context of sustainable development" (Müller and Weigelt, 2013). This agreement was further developed during the subsequent process to define Sustainable Development Goals (SDGs), approved by the UN General Assembly in September 2015 (Table 1). This soft-law process reflects the growing interest in the development of a universal and transformative agenda that provides a global vision for sustainable development, linking environmental, economic and societal issues. Main difference to the previous Millennium Development Goals (MDGs) is that the SDGs are applicable by all countries in the world, not just by developing countries. Every nation now has to implement these goals in order to achieve the agreed targets by 2030 .

Every scientific discipline faces the challenge of acting upon these SDGs, and this is particularly relevant for soil science, as a land-related discipline with important links to several of the SDGs. In this forum paper we explore and discuss how soil scientists can rise to the challenge both internally, in terms of our procedures and practices, and externally, in terms of our relations with colleague scientists in other disciplines, diverse groups of stakeholders and the policy arena.

\section{Addressing the Sustainable Development Goals}

The broad SDGs (Table 1) are intended to be a guideline for all governments. Some goals are mainly socio-economic in character (e.g. goals 1, 4, 5, 8-11,16,17), while others focus 
Table 1. The UN “Sustainable Development Goals” for the period 2015-2030 (http://sustainabledevelopment.un.org/focussdgs.html), related to ecosystem services and soil functions, as discussed.

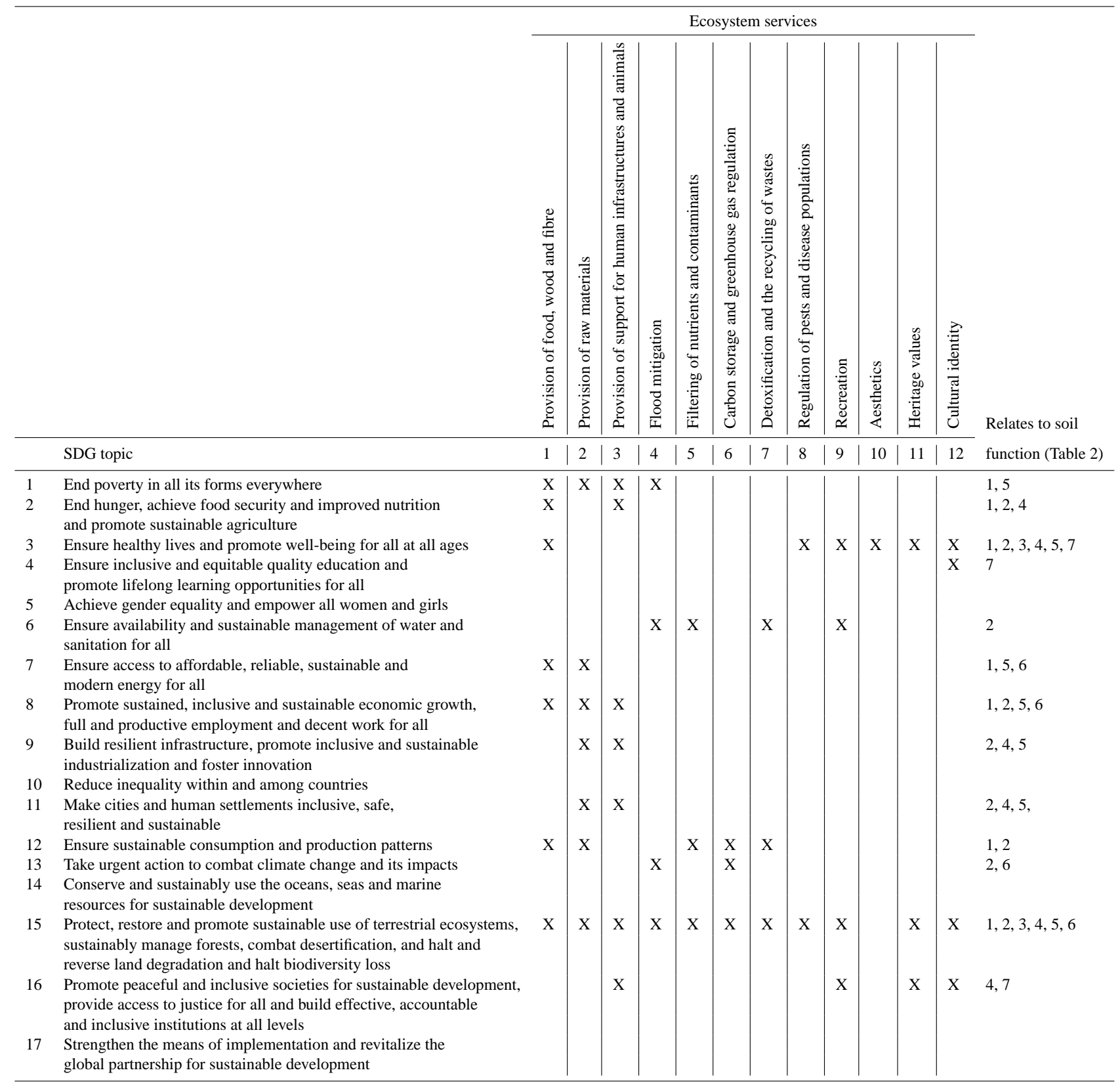

clearly on the biophysical system, in which soils play a clear role (e.g. goals $2,3,6,7,12-15$ ). Although it is tempting to make the distinction between a focus on socio-economics and on the biophysical system, these two realms together define human existence and mutually depend on each other. For achieving goals with a socio-economic focus we need to consider the associated dynamic behaviour of ecosystems, while for achieving goals with an ecosystem focus, we need to consider socio-economic aspects. Environmental sustainability will depend on the actions of land users such as farmers and forest managers, but also urban developments have major effects on local land use. The SDGs present a real challenge to the citizens of the world and their various policy arenas. The scientific community has a responsibility to provide all stakeholders with information that allows them to make informed choices. We believe that the introduction of SDGs in the 2015 International Year Of Soils offers a new and unique opportunity for the soil science community to show that soil science can make significant contributions to several of the SDGs. Although this notion is clearly growing, we feel that a 
Table 2. The seven soil functions (SFs) as defined by the European Commission (EC, 2006).

1 Biomass production, including agriculture and forestry

2 Storing, filtering and transforming nutrients, substances and water

3 Biodiversity pool, such as habitats, species and genes

4 Physical and cultural environment for humans and human activities

5 Source of raw material

6 Acting as carbon pool

7 Archive of geological and archaeological heritage

well-focused action is needed to urge fellow (soil) scientists, members of the policy arena and stakeholders and citizens at large to act according to this notion. Actions needed are different for each of these groups; in this forum paper we will focus on the implications for actions by the soil science community. Important educational efforts for stakeholders and the public at large, with particular attention for primary education of children, have been addressed elsewhere (Bouma et al., 2012).

It is important to recognize that, for most SDGs, there is no direct link with soils. Rather, soils contribute to general ecosystem services, defined as "services to society that ecosystems provide", which requires cooperation between different disciplines (e.g. De Groot et al., 2002; Dominati et al., 2014; Robinson et al., 2013). Ecosystem services contribute to nearly all land-related SDGs, either directly or indirectly. Table 1 shows ecosystem services as they are now recognized in the soil literature (e.g. Dominati et al., 2014). The question can be raised as to how input of soil expertise can be most effective when defining ecosystem services. A logical way to consider soil contributions to interdisciplinary studies on ecosystem services is to consider the seven soil functions, as defined by the European Commission (EC, 2006) (Table 2). Thus, an operational sequence is defined starting with the SDGs, next considering relevant ecosystem services and the contributions that the soils can make to improve those services (see also Fig. 1). Most applied soil studies can be expressed in terms of their relevance for certain SDGs, also indicating which ecosystem services and associated soil functions play an important role. This new possibility for framing soil studies offers an opportunity to increase the visibility and recognition of the work in soil science as a much wider audience is being addressed. Bouma et al. (2015) illustrated this reframing process for six published studies on soil and water management in the Netherlands and Italy.

A clear framework linking SDGs, ecosystem services and soil functions will also pave the way towards a more relevant contribution of the soil science community to ongoing major global and regional ecosystems assessments related to land and soils. The most obvious example is the currently ongoing Land Degradation and Restoration Assessment (LDRA) of

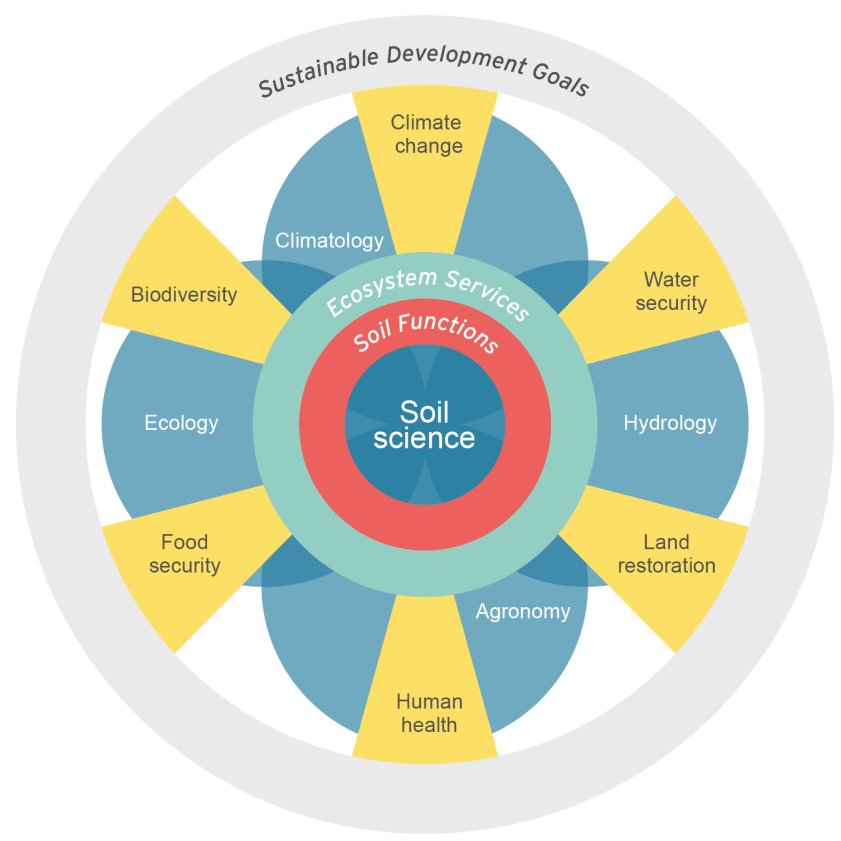

Figure 1. Six major global issues, each of which relates to one or more of the SDGs: (i) food security; (ii) human health; (iii) land management, including land restoration; (iv) water security; (v) climate change; and (vi) biodiversity preservation. Each of these issues will be discussed in short essays, loosely based on discussions held at the EGU Soil Conference in Vienna in April 2015 and at the Wageningen Conference on "Soil Science in a Changing World" in August 2015.

the Intergovernmental Platform for Biodiversity and Ecosystem Services (IPBES), planned for final release in early 2018. Similar to IPCC, these assessments by IPBES will be the main scientific reference for future policy development on terrestrial ecosystems at global, regional and national scale.

Overall, we should acknowledge that services are provided by nature, and that human efforts should be governed by the realization that every ecosystem has its own, characteristic dynamics and thresholds. Sustainable development can only be achieved when taking into account processes, feedbacks and thresholds in the ecosystem.

In summary, the aim of this forum paper is therefore to discuss how soils can contribute to the realization of the SDGs. We urge soil scientists to pursue a central role in the system analysis approach that is needed to confront the societal challenges of our time. For this we argue why soil scientists need to reach out to other scientific disciplines, and to stakeholders outside of science. Awareness raising on all levels in society will play a key role in this. Six short essays, written by invited experts expressing their personal impressions, feature prominently in this forum paper, and serve to introduce the discussion, covering key issues for soil science that are also part of several of the SDGs: food, health, water, climate and land management. This paper also serves as an introductory forum paper to this special issue on "Soil Science in a Chang- 
ing World", which contains selected contributions of participants of the Wageningen Soil Conference (Wageningen, August 2015), and to the EGU Union Symposium "Soil Science within an interdisciplinary framework" (Vienna, April 2015).

\section{The six main issues}

Essay 1. Food security (SDGs 1, 2 and 3): soil fertility and the role of soils for food security in developing countries

Addressing current and future food security is not just a matter of producing more food globally. Agricultural productivity must increase where food is most needed, and where both rural and urban populations are expected to increase the fastest in the near future. This is the situation in most of subSaharan Africa and in several other regions of Latin America, Asia and the Pacific (UNDESA, 2013). There are some common denominators to these regions: first, the inability of the majority of smallholder farmers to access and/or to afford agricultural inputs (Pretty et al., 2011; Tittonell, 2014); second, the severity with which climate change impacts on some of these regions (Thornton et al., 2014); third, the extent of soil degradation, which is estimated at $25 \%$ of the arable land in the world (Vlek et al., 2008); and finally, the fact that some of these regions are hosting valuable biodiversity and/or delivering ecosystem services of global or regional importance (Hooper et al., 2005), which often leads to competing claims between local and international communities.

It has been repeatedly shown that the technologies of industrial agriculture as practiced in developed regions are ineffective at sustaining soil productivity in the context of smallholder family agriculture (Tittonell and Giller, 2013). Restoring soil productivity and ecosystem functions in these contexts requires new ways of managing soil fertility. These include the following:

i. Innovative forms of "precision" agriculture that consider the diversity, heterogeneity and dynamics of smallholder farming systems. Precision agriculture implies more than just using GPS; it is also about targeting resources in space and time to increase efficiency, build resilience and reduce negative impacts; local knowledge can be the basis for precision agriculture in developing countries. For example, evidence from 3600 farmers' fields in Madagascar shows that knowledge-based precision management of different nutrient sources can increase efficiency and reduce yield variability in climatically vulnerable environments (Bruelle et al., 2015).

ii. A systems approach to nutrient acquisition and management. Agronomy has traditionally addressed the problem of crop nutrition by thinking and acting at the scale of individual fields, and often looking at single resource groups; however, nutrient management cannot be decoupled from management of other farm resources and processes such as recycling are crucial to overall systems efficiency. For example, ecological network analysis of nutrient flows in smallholder crop-livestock systems of eastern and southern Africa revealed that system productivity depended more on recycling efficiency than on annual nutrient inputs (Rufino et al., 2009; Castellanos-Navarrete et al., 2015).

iii. Agro-ecological strategies for the restoration of degraded soils and the maintenance of soil physical properties. Rural population growth in tropical regions of developing countries is leading to accelerated soil degradation, as more land previously under forest or grazing use is brought into annual cultivation; less land available per household prevents soil maintenance practices such as fallow or pasture rotations, leading to greater frequency of soil ploughing and less organic matter inputs (e.g. Diarisso et al., 2015). Strategies are needed to restore degraded soils and halt current degradation processes in precious land to produce food, but this also requires new institutional arrangement around land tenure and collective resource management (Baudron et al., 2014). This may involve a large-scale approach and multi-stakeholder partnerships built on new business models with multiple returns from sustainable land management and landscape restoration (Ferwerda, 2015). Proof of concept of such management strategies to restore degraded soils and reduce soil threats have been reported in literature (e.g. Araya et al., 2012; Corral-Nunez et al., 2014; Nezomba et al., 2015).

iv. To capitalize on the recent and growing understanding on the soil food web to increase nutrient and water use efficiency; the association between nutrient capture and retention in soils and trophic network topologies points to promising avenues towards the design of more efficient and resilience cropping systems; management systems that rely on greater diversity such as agroforestry and intercropping lead to greater diversity of soil organisms, and a range of hypotheses on how this can contribute to improve agricultural sustainability are being put forward (see Essay 5).

\section{Essay 2. Health (SDG 3): soil and public health - a vital nexus}

Throughout the history of civilization, relationships between soils and human health have inspired spiritual movements, philosophical systems, cultural exchanges, and interdisciplinary interactions, and provided medicinal substances of paramount impact. Modern public health - in its efforts in preventing disease, prolonging life and promoting health through organized activities and informed choices of society - faces the need of understanding and managing interactions between soils and health. Given the climate, resource, and population pressures, such understanding becomes an 
imperative. Soils sustain life. They affect human health via quantity, quality, and safety of available food and water, as a source of essential medicines, and via direct exposure of individuals to soils.

We are witnessing a paradigm shift from recognizing and yet disregarding the "soil-health" nexus complexity to parameterizing this complexity and identifying reliable controls. This becomes possible with the advent of modern research tools as a source of "big data" on multivariate nonlinear soil systems and the multiplicity of health metrics. These advances, in particular, have enabled the demonstration of the dependence of human pathogen suppression in soils and plants on the soil microbial community structure, which, in turn, is directly affected by the soil-plant system management (Vivant et al., 2013; Gu et al., 2013). Soil eutrophication appears to create favourable conditions for pathogen survival (Franz et al., 2008), providing another reason to restrict the eutrophication process.

The soil microbial community structure also strongly affects soil structure (Young and Crawford, 2004). This, in particular, affects functioning of soils as a powerful water filter and the capacity of this filter with respect to contaminants in both "green" and "blue" waters.

Also, soils remain an indispensable source of new powerful antibiotics able to counter the antibiotic resistance dilemma (Ling et al., 2015) and potent medicines to treat such tough-to-treat diseases as tuberculosis and cancer (Hartkoorn et al., 2012; Liu et al., 2002). Some links between soil and human health tie exposure to soils, to immune maturation and, in particular, to asthma prevention (von Hertzen and Haahtela, 2006; Rook, 2013) and mental well-being (Lowry et al., 2007).

To evaluate effects of soil services to public health, upscaling procedures are needed for relating the fine-scale mechanistic knowledge to available coarse-scale information on soil properties and management as health factors. In this context, remarkable advances of medical geology resulted in identification of regions where soils contain components harmful for human health (Selinus, 2013). These results have to be downscaled to evaluate local risks. More needs to be learned about health effects of soils in organic agriculture that are often used for soil quality comparison and benchmarking. The influence of soil degradation and rehabilitation on public health has to be assessed in quantitative terms (Zubkova et al., 2013). Current definitions of healthy soil broadly include aspects that are conducive for human health, and functional evaluation of soil quality with a focus on public health will have useful applications in public policies and perception. The data on soil-health relationships are scarce and very much disjointed, and a concerted international effort appears to be needed to encompass various economic and geographical settings (Brevik and Burgess, 2012). The "soil-health" connection is complex in character, global in manifestation, and applicable to every human being.
Essay 3. Water security/resources (SDGs 3,6): soil water and sustainable development goals

Protecting and enhancing the ability of the Earth's soils to provide clean water in sufficient quantities for humanity, ecosystems and agriculture will be a key element in delivering the SDGs. Soils are key for storing and transmitting water to plants, the atmosphere, groundwater, lakes and rivers. It is estimated that $74 \%$ of all freshwater appropriated by humans comes from the soil (Hoekstra and Mekonnen, 2012). Soils are not only important for storing and supplying water; they also filter it. Soils are bioreactors. They contain charged surfaces at which exchange reactions can occur, such as bacteria, fungi and soil animals that process nutrients and contaminants, and act as a medium to support plant growth that cycles nutrients and water through the ecosystem. SDG 6 challenges the world to ensure availability and sustainable management of water and sanitation for all. This will not be achieved without protecting and enhancing the ability of the soil to deliver clean, fresh water. Safe affordable drinking water (SDG 6.1) will rely on water sources that are reliable and uncontaminated. For 2010 it was estimated that as much as $60 \%$ (Baum et al., 2013) of the world's population is not connected to municipal sewage treatment systems, suggesting that the remaining $40 \%$ of waste water receives no treatment. SDG 6.3 targets halving the proportion of untreated wastewater by 2030 . In rural areas this will likely take the form of installing variants of septic systems, which rely on the soil for decontaminating wastewater. It is also likely that soils will be required to recycle a larger proportion of solid wastes and wastewater (SDG 6.3) from cities and it will be important to understand the capacity of soils to process these inputs and their capacity for assimilating these materials. The provision of water for crops is of global significance, and making the use of this water more efficient (SDG 6.4) is a major challenge. Agriculture amounts to $92 \%$ of the globe's freshwater use, far ahead of industrial and domestic usage (Hoekstra and Mekonnen, 2012). Of the $6685 \mathrm{~km}^{3}$ year $^{-1}$ of water calculated to be used by crops (Siebert and Döll, 2010), it is estimated that $800-1100 \mathrm{~km}^{3}$ year $^{-1}$ is supplied for irrigation from rivers, lakes, reservoirs and groundwater (Döll et al., 2014), as we strive to deliver food security (SDG 2) the volume of water required from these sources is likely to increase. By protecting and enhancing the soil's ability to store and supply water to plants through better soil management there is the potential to make better use of rainwater. By enhancing the plant available soil water across the irrigated land (Siebert et al., 2015), the additional water could be used by crops and reduce irrigation water requirements.

Soil is the conduit for the vast majority of diffuse pollutants. Nutrients from agricultural sources are responsible for the pollution of lakes, rivers and seas, in many cases bringing about significant degradation of their ecosystems and damaging them as economic and social resources for the peo- 
ple who rely on them for their well-being. Restoration of these ecosystems will require restorative actions in the wider catchment, including better soil management to reduce diffuse pollution (Deasy et al., 2009). However, although soils are excellent buffers against diffuse pollution, they are also slow to change. Therefore, if water-related ecosystems are to be restored by 2030 in line with SDG 6.6, significant actions will need to occur urgently.

Managing soils for a better water environment cannot occur without the support and efforts of local communities, many of whom fully understand the inexorable link between soils and water, their efforts need to be supported and strengthened (SDG 6.8).

\section{Essay 4. Climate change (SDG 13): impact of climate change on soils and opportunities for mitigation}

Predicting the response of soils to climate change is extremely important as the top metre of soils globally contains 3 times as much carbon as the atmosphere (Smith, 2004). Small changes in soil carbon stocks can therefore have important impacts on climate - if soil carbon is lost, it could provide a positive feedback to climate warming (Cox et al., 2000). On the other hand, if soils can be managed to store more carbon, they can help to reduce the amount of carbon in the atmosphere, and thereby mitigate climate change (Lal, 2004). This is the aim of the recent proposal at the COP 21 of UNFCCC by the French government for a global initiative (http://agriculture.gouv.fr/ sites/minagri/files/4pour1000-gb_nov2015.pdf) for achieving a " $4 \% o$ " annual growth rate of the soil carbon stock, which would make it possible to stop the present increase in atmospheric $\mathrm{CO}_{2}$.

Climate change has complex impacts on soils. Increasing temperatures will tend to increase decomposition, but this will be limited where soils become very dry - so changes in temperature and precipitation can have additive effects, or may work in opposite directions. In addition, increasing temperatures can also increase plant production, thereby increasing carbon inputs to the soil. This may also decrease the direct impact of climate change on soils and may increase soil carbon (Smith, 2012). Changes in precipitation patterns and amounts will also influence soil organic carbon stocks through their effect on dissolved organic matter production and mobility (e.g. Jansen et al., 2014). This not only affects the soil carbon stock itself but also couples it to the carbon cycle in aquatic systems (Jansen et al., 2014). While climate change clearly affects soil organic carbon stocks, the magnitude of the effect depends on the intricate interplay of local external factors, such as climate, and the ecosystem-specific composition of the organic matter itself that steers its interactions with the inorganic soil phase (Schmidt et al., 2011). As a result, not only soil organic carbon stocks but also their predicted response to climate change vary between ecosystems (e.g. Tonneijck et al., 2010).
Nevertheless, while modelling studies (Gottschalk et al., 2012) confirm there is considerable regional variation, with some regions gaining in carbon and some regions losing carbon, globally, climate change is projected to increase soil carbon stocks on mineral soils (i.e. non-peaty soils). On the other hand, peatlands, which contain enormous stocks of carbon (similar to the quantity of all carbon in the atmosphere), may be more susceptible to climate change. When these soils heat up, or if they become drier, vast quantities of carbon could be lost. Similarly, permafrost soils may lose carbon when they thaw (Joosten et al., 2015).

Given the complex interactions between temperature and moisture, between increased productivity and increased decomposition, and variations between regions and different types of soil, predicting the composite effects of climate change on soils is extremely difficult (Smith et al., 2008a).

As well as soils being affected by climate change, improvements in soil management can be used to reduce greenhouse gas (GHG) emissions or increase soil carbon stocks (Lal, 2004; Smith, 2012). Soil management can therefore be used as a climate mitigation option (e.g. Tonneijck et al., 2010). This is important for climate mitigation, as well as for meeting SDGs, since SDG 13 is to "take urgent action to combat climate change and its impacts".

Results from a recent global analysis of GHG mitigation options in agriculture (Smith et al., 2008b) show that there is significant potential for soils to mitigate GHG emissions but that the realization of this potential will depend on the price of carbon. The maximum technical mitigation potential from soil carbon sequestration is around $1 \mathrm{Gt}$ (thousand million tonnes) of carbon per year, but the economic potential at carbon prices between USD 20 and 100 per tonne of $\mathrm{CO}_{2}$ equivalents is $0.4-0.7 \mathrm{Gt}$ carbon per year (Smith et al., 2008b; Smith, 2012). This means that soil carbon sequestration could be an important part of future climate mitigation portfolios.

\section{Essay 5. Biodiversity (SDG 15): functions of soil biodiversity}

SDG 15 aims to "sustainably manage forests, combat desertification, halt and reverse land degradation, and halt biodiversity loss". It recognizes that soil microorganisms and invertebrates are key to ecosystem services, but highlights that their contributions are poorly understood and rarely acknowledged. A large fraction of the Earth's biodiversity can be found underground. One square metre of land may contain as many as 20000 "species" of viruses, bacteria, fungi, protozoa, nematodes, enchytraeids, collembolas, mites, earthworms, insects, and some vertebrates. There is mounting evidence that this soil biodiversity contributes to biogeochemical cycles; above-ground biodiversity; soil formation; the control of plant, animal, and human pests and diseases; and climate regulation. Soil biodiversity also contributes to ecological-evolutionary dynamics in ecosystems, which is 
important for mitigation and adaptation to human-induced global changes in climate, land use, and species gain and loss (Bardgett and van der Putten, 2014).

Although much is still to be learned about the distribution of soil biodiversity across the globe, it is becoming evident that it is negatively affected by many human activities, including land use change and management intensification. The first global assessment of soil biodiversity has been completed by the Global Soil Biodiversity Initiative (GSBI) and will be presented as the Global Atlas of Soil Biodiversity, due to be released early 2016 (https://globalsoilbiodiversity.org/ ?q=_node/271). Studies at a continental scale have shown that land use intensification universally reduces the species diversity, especially of the larger-sized soil organisms (Tsiafouli et al., 2015), which may negatively impact multiple ecosystem functions and services (Wagg et al., 2014) as well as their resistance and resilience to extreme climate events, such as drought, leading to enhanced carbon and nitrogen loss to the drainage and ground water during subsequent rainfall events (de Vries et al., 2012). Land use intensification, therefore, may result in loss of ecosystem stability with negative consequences for the Earth's atmospheric composition and water quality.

Loss of soil biodiversity might also result in decreased control of plant, animal, and human diseases (Wall et al., 2015); modify vegetation dynamics (Bardgett and van der Putten, 2014); and impact soil physical properties, with consequences for ecosystem services related to soil formation and water regulation (Six et al., 2002). There is evidence that soil biodiversity is also susceptible to invasions and extinctions, nitrogen enrichment (Treseder, 2008), soil sealing (Gardi et al., 2013), and climate change (Blankinship et al., 2011). Also, predicted increases in soil erosion and climateinduced shifts in land use pose a considerable threat to soil biodiversity; however, in all these cases, the full magnitude still needs to be established, even though a great deal of recent data has become available (e.g. Ramirez et al., 2015). Moreover, there are several complications in doing so, including our limited knowledge on what biodiversity is actually present in soils, and its enormous variation in spatial distribution from micro- to macroscale (Ettema and Wardle, 2002; Bardgett and van der Putten, 2014). Many factors have been identified as determinants of soil biodiversity patterns, including $\mathrm{pH}$, soil structure, soil organic matter, and plant diversity and composition, but the relative contributions of each of these factors is still largely unknown. Measures that may promote soil biodiversity include reduced soil tillage, increasing soil organic matter, erosion control, prevention of soil sealing and surface mining activities, and prevention of extreme soil perturbation.
Essay 6. Land management (SDG 2, 13, 15): the challenge to implement effective soil conservation.

Sustainable development goal 15 focuses on sustainable use of terrestrial ecosystems, combat desertification, and halt and reverse land degradation. Many ecosystem services and soil functions (Table 1) are connected to this SDG. To reach the desired sustainable situation, good land management plays an essential role. To illustrate the way ahead for in land management, the fragile ecosystems of the Mediterranean are taken as an example. When looking back in time, the Mediterranean landscape was managed in a sustainable way for millennia. This changed the landscape (e.g. terraces) and ecosystems (e.g. extensive irrigation systems) to a man-made system (Boogaard, 2005; Stanchi et al., 2012). However, over the last 30 years the land management strategies have changed due to altered socio-economic conditions. These changes led this sustainable system to be pushed towards, and sometimes over, certain thresholds that caused the system to collapse (Lesschen et al., 2008; Arnaez et al., 2011). To illustrate, we can observe that, since the 1960s, there have been two contradictory trajectories in the management of soil developments. On the one hand, part of the traditionally fully agronomy-oriented society has been altered, resulting in abandoned ghost towns and whole regions that lost most of their population and were abandoned (Lansata et al., 2005). Former fields and terraces are now overgrown and shrubs and sometimes a full forest have developed. This has compromised many of the ecosystem services as listed in Table 1 and, in addition, causes a threat to society due to an increase in the risk of wild fires resulting from the abundant fuel in the new forests. To reach a sustainable situation as described in SDG 15, there is an urgent need to reduce the large wildfires by re-introducing extensive forms of agriculture and grazing in the Mediterranean mountains, thereby reducing the risk of fires and the environmental problems they trigger: soil erosion, water pollution, and changes in landscapes and soil properties (Cerdà and Lansata, 2005).

The other trend that can be observed in many countries around the Mediterranean is agricultural intensification. Small-scale, sustainable orchards are removed to make room for large-scale orchards that are under drip irrigation that contains all nutrients for the plants, making the soil no longer a needed resource for the land owner (Cerdà et al., 2009b). Intensification of industrialized agriculture may lead to excessive application of agrochemical leading to pollution of ground and surface waters and to erosion when lower organic matter contents result in a decrease in quality of soil structure. This kind of agriculture may be economically attractive; while the traditional farming systems are no longer economically viable, the sustainability of these new systems is bringing us further away from reaching the objectives of SDG 15. In addition, farmers cling to habits such as keeping their soil "clean", without weeds; erosion prevention measures such as mulching and cover crops are seen as sloppy 
management, even though these kind of practices are known to aggravate soil erosion (e.g. Keesstra et al., 2009, 2016; Cerdà et al., 2009a, b).

Soil management in Mediterranean-type ecosystems needs a new generation of managers, farmers, policy makers, and also scientists that will understand the importance of the soil system. For this, education programmes are needed, starting at primary school level. Educating the people to acknowledge the importance of soil for soil functions and, in the end, ecosystem services that are important for all may lead to the promotion of organic farming, mulching and minimum or zero tillage. However, the opinion of consumers and the public can also have a strong impact. The public should be aware of the possibility of choosing products of higher quality while environmental pollution with agrochemicals is strongly reduced.

\section{Additional information}

Essay 1 was contributed by Pablo Tittonell; Essay 2 by Yakov Pachepsky; Essay 3 by John Quinton; Essay 4 by Pete Smith and Boris Jansen; Essay 5 by Wim van der Putten and Richard Bardgett; and Essay 6 by Artemi Cerdà and Saskia Keesstra.

\section{Actions to be taken}

The six short essays above illustrate the role that soils play when studying major environmental issues, many of which related to SDGs, as indicated (Tables 1 and 2). Clearly, more cooperation of soil scientists with agronomists, hydrologists, climatologists, ecologists, social scientists and economists (see also Fig. 1) in interdisciplinary research is desirable to derive meaningful contributions to general ecosystem services, and recommendations to this effect have been made before and are therefore hardly enlightening anymore. Here, we would like to emphasize two other issues that we think are crucial for future activities in soil science. The first issue is the need for a systems approach, where soil science provides leadership as the environmental issues discussed are interconnected and land-related and the relevant processes interact in the pedosphere. The second issue is that the potential of soils to contribute to solving the major societal challenges of our time, represented by the SDGs, can only be obtained if we succeed in raising awareness of the crucial importance of soils in supporting life and livelihoods. Such awareness should register more clearly with the general public, stakeholders, business leaders and policy makers.

\subsection{The need for a systems approach}

Ecosystems are characterized by interacting geological, hydrological, climatological, ecological and anthropogenic processes. Due to strong interactions between these processes, a systems approach is needed to understand the response to changing circumstances in any of the individual elements; feedbacks within the system may result in unexpected and/or delayed responses to changes. Approaches will have to reach across levels of integration - in biological terms from species to communities to ecosystems - as has been achieved in ecosystem studies linking below-ground activities to aboveground plant development (e.g. Bardgett and Wardle, 2010). In soils, pedon studies are scaled up to catenas, watersheds, regions and beyond. Food security, for example, is strongly affected by available nutrients and water resources, climate change, land management and biodiversity preservation, which have different effects at different spatial and temporal scales, and the same is true for each of the separate issues in relation to all the others. The type of land use determines these interacting processes, and as soils are a key element in determining land use, they provide a solid foundation for a systems approach. Soil scientists are in a unique position to act in this capacity. Their history includes extensive interaction with stakeholders when, for example, developing fertilization practices, preparing soil surveys and combatting land degradation considering important social and economic aspects (e.g. Adimassu et al., 2014; Musinguzi et al., 2015).

At this point in time the question can be raised as to who will seize the initiative to start such broad inter- and transdisciplinary studies, focusing on ecosystems but with a clear soil component (interdisciplinarity refers to disciplines working together; transdisciplinarity also involves stakeholders). Funding agencies such as the EU HORIZON 2020 and its predecessors have clear ambitions to realize this type of research approach and many ecological and climatological system studies have been made, particularly for larger regions. But integrating climatological, hydrological, agronomic and ecological aspects is more difficult, certainly when including socio-economic aspects. The six major environmental issues, covered in the six essays relating to SDGs presented above, are land-related, and soil scientists are therefore in a natural, but also highly challenging, position to initiate, guide and complete systems analyses of ecosystems, working with fellow scientists, stakeholders and policy makers. This applies at different spatial scales, ranging from fields, farms and regions to the world at large. It also applies at different temporal scales, ranging from present-day processes to geological times in order to understand system responses and feedbacks.

Such integrated studies are still relatively rare, thus presenting a new research "niche". An example is a comprehensive, integrative study of innovative dairy systems in the Netherlands using life cycle assessment to characterize the entire production chain, including an economic and energy analysis. Improvement of nutrient cycling resulted in improved groundwater quality; lower emissions of GHGs and lower energy use; and higher incomes as well as organic matter contents of the soils, the former due to lower costs. Biodiversity was high because of preservation of hedgerows along relatively small fields. Dolman et al. (2014) presented results at farm level and de Vries et al. (2015) scaled the work up to a 
regional level. Van Grinsven et al. (2015) extended the work to a broad policy analysis, considering future development scenarios.

In the end, effective communication of results to citizens, stakeholders and policy makers is crucial, and the example of the UNFCCC, which defines "lighthouses" for successful case studies, is inspirational in this context.

\subsection{Creating and sustaining awareness}

Raising awareness by establishing genuine two-way dialogues requires different approaches when addressing policy makers, stakeholders, the public and colleagues in other disciplines. To improve the connection with policy makers, it is important to consider their way of reasoning, and two approaches may be helpful in this context. The first of these is the policy cycle when planning and executing research, which includes signalling and definition of a given problem taking into account the opinions of all involved, design, decision, implementation and evaluation (e.g. Althaus et al., 2007; Bouma et al., 2007). In many current research projects, most of the time is spent on design, and relatively little time is spent signalling, which may lead to hastily conceived plans and disengagement of stakeholders who feel left out. Also, implementation is often seen as the responsibility of others while it is crucial to demonstrate - if successful - the relevance of soil science in the design and implementation of such projects (e.g. Bouma et al., 2011). Nothing is as convincing as a successful project. The second, the DPSIR approach (Skondras and Karavitis, 2015), can be useful when performing land-related research, as it distinguishes external drivers, pressures, impacts and responses to land-use change that affect the state of the land in the past, present and future (e.g. van Camp, 2008; Bouma et al., 2008; Mol and Keesstra, 2012).

So, rather than jumping right away into agronomic, hydrological, climatological and ecological studies, or even into a comprehensive systems analysis, the current land-use drivers, the pressures they generate and the impact they have should be signalled. In doing so, it pays to involve stakeholders and policy makers at an early point in a "joint-learning" mode, also referred to as co-production of knowledge. This includes characterization of current conditions as well as a range of possible future conditions as a source for decisions to be taken. In close interaction with all stakeholders involved, possible alternatives should be designed and ways explored to have one of them approved and implemented. The design phase involves major input by research, acknowledging that much information and knowledge is already available, as is clearly demonstrated in the first six essays. New research can be based on observed gaps during the signalling and design process.

Stakeholders have a direct personal or commercial interest in the way land-use issues are investigated. SDGs have a societal focus, and future soil science research can only be successful if stakeholders are part of the research effort in transdisciplinary projects, based on the principle of timeconsuming "joint learning", which is facilitated by providing accessible narratives about case studies (Thomson Klein et al., 2001; Bouma et al., 2015; Bouma, 2015b). The increasing importance of transdisciplinarity also implies that the "top-down, command-and-control" character of much current environmental legislation should evolve into a "bottomup, joint-learning" mode that truly engages modern stakeholders and is an important ingredient of adaptive management (e.g. In't Veld, 2010). Projects using citizen science are one additional interesting tool to involve stakeholders and the general public (Bonney et al., 2014). The further development of such projects and the development of voluntary soil governance instruments is the way forward for such innovative bottom-up participatory approaches. Strengthening voluntary partnerships, like the Global Soil Partnership (GSP), could ultimately lead to a more effective sustainable soil management then many of the (largely not implemented) mandatory legal frameworks (Montanarella, 2015a, b). However, awareness is hampered by the gradual and slow character of changes in the pedosphere. Even abrupt changes in driving forces (e.g. climate, land management) will result in slow changes in soil properties and often a delayed response in the quality of soil ecosystem services. Such gradual and delayed behaviour does not attract the kind of attention reserved for natural hazards like volcanic eruptions, earthquakes, tsunamis and floods. Yet the consequences of soil degradation for society as a whole will be more severe than any of those (local) phenomena. Another issue is, that with the green revolution, the connection of food and soil has lost visibility and importance (Essay 6). Not only are city dwellers less aware of where their food in the supermarket originates from, some farmers even consider their land as an industrial production factor that can be manipulated at will, ignoring ecological thresholds. Essay 1 articulates relevant approaches for resource-poor small-scale farmers in developing countries. But questions have been raised whether or not high food demands of mega-cities in future will require a significant productivity increase of land and labour that is associated with more large-scale farming (e.g. De Ponti et al., 2012). That new and effective antibiotics are being derived from soil and that human health can be negatively affected by soil-borne diseases, as described in Essay 2, is unknown to the public. The international One Health Initiative (http://www.onehealthinitiative.com) focuses on links between human and veterinary medicine and environmental science but has so far paid little attention to soils. The public at large does not recognize the crucial and fundamental importance of biodiversity to life on Earth, as discussed in Essay 5. That the quality of ground and surface water is, to a large extent, governed by percolation through soil or by surface runoff that may result from soil compaction or surface sealing (Essay 3 ) is unknown as well. The facts that there is more organic matter in soils than in all the tropical forests 
combined and that carbon sinks in soil present a major mitigation opportunity (as described in Essay 4) have drawn considerably less attention than reducing $\mathrm{CO}_{2}$ emissions. Therefore, proper communication of the role of soils, applying modern communication practices, is urgently needed, taking a positive approach and emphasizing successful examples and programmes. Complaining that soils have not received the attention they deserve serves no useful purpose.

Creating awareness with colleague scientists presents an intriguing dimension to this discussion. The need for interdisciplinarity has been discussed above. But how can interdisciplinarity be realized? Scientists of a given discipline are only accepted as partners in interdisciplinary projects if they can deliver input that is considered to be of substantial added value by the other partners. Many agronomists, hydrologists, climatologists, and ecologists, not to mention economists and sociologists, are not aware of what soil scientists have to offer. A recent example on "climate-smart agriculture" by Bonfante and Bouma (2015) illustrates this point. By running a crop production simulation model, considering the effects of climate change, growing 11 maize hybrids and using different degrees of irrigation water availability for a Mediterranean area, they showed that agronomic and irrigation plans had significantly different effects on different soil types occurring in the area. These results allowed rational future planning of cropping and irrigation schemes and were welcomed by farmers and irrigation engineers, who were rather surprised to see these soil-based results. An example for developing countries demonstrated within-farm nutrient gradients which strongly affected yield response requiring alternative location-specific approaches, in contrast to the traditional blanket application of fertilizers (Tittonell et al., 2008). Again, documentation of soil differences had a significant effect on management. Of course, there are more of such examples and they should be presented more prominently.

The example of the UNFCCC, producing "lighthouses" for successful programmes, is inspiring in this context because presenting soil-based "lighthouses" is the overall connecting theme for awareness raising. The good news is that many "lighthouse" examples are there, but we have not yet recognized the urgency to communicate these examples in an effective manner, also showing what might have happened without soil science input. Modern communication is a science, or better an art, that cannot be accomplished solely as a side activity by scientists who were trained in entirely different fields. Many of our current scientific journals are not focused on publishing "lighthouse" papers, and finding appropriate outlets for this work is still a challenge (e.g. Bouma, 2015a). As for the MDGs, there is the need to demonstrate that the SDGs can be implemented successfully at the local level. As the Millennium Villages Project (Sanchez et al., 2007) has been demonstrating for the MDGs, there is the need for a similar project for the SDGs in the future.

\subsection{How to overcome constraints}

To be realistic, several constraints have to be recognized when proposing a central role of soil scientists in initiating and guiding inter- and transdisciplinary projects, aimed at land-related aspects of the SDGs. Constraints when raising awareness have already been discussed above, but social and economic constraints as well as policy barriers require additional attention.

The first level of constraint is social. As we learn from Essay 6, a good farmer in Spain is considered to be a farmer that keeps his or her fields tidy and clean, apparently unaware of the resulting vulnerability to erosion in sloping areas. A farmer that leaves weeds on the field is considered to be a sloppy farmer by peers. Even though there is a wealth of information on successful forms of soil management that leads to less erosion and degradation (e.g. WOCAT, 2007; Schwilch et al., 2012; Cerdà et al., 2016) implementation in practice is delayed, often for social reasons. Intensive agricultural practices that are accepted by commercial farms may lead to environmental pollution by biocides and excess fertilizers (Roy and McDonald, 2013; Shi et al., 2015; Sacristàn et al., 2015). The language and perceptions of farmers and environmentalists are still quite different, even though mutual understanding has increased in many countries. In developing countries, the situation is often even more difficult because of population growth, increasing the pressure on land and water resources. Land vulnerable to degradation is taken into cultivation with adverse effects on the soil functions and ecosystem services (Fialho and Zinn, 2014; Olang et al., 2014; Costa et al., 2015). Competing claims on land by industry, urban sprawl, agriculture and nature are all too often not decided by rational arguments but by political or ideological arguments. To disrupt this negative discourse and provide a counterweight to negative social pressures, education is important, and so are specific examples of successful management systems. But most convincing may be a demonstration that good environmental practices can correspond to positive economic effects: "what is good for the environment can be good for business" (see also Essay 1) - after all, "money talks". Fine-tuning application of agrochemicals to the needs of the plants can, for example, strongly reduce costs for the farmer, increasing net income while soil quality is improved (e.g. Dolman et al., 2014; de Vries et al., 2015); and reduce the pressure on the natural ecosystem. Many positive examples are there to be shown and this deserves more attention in future. Intercropping, strip cropping or the use of mulch can result in higher yields, stronger resilience and larger biodiversity (Whitmore and Schroeder, 2007; Novara et al., 2013; Laudicina et al., 2015). With appropriate land management, intensified farming may result in higher production combined with increased soil organic matter content.

The second level of constraint is economic. Farmers everywhere have to make a living, and economic results of any commercial farming operation must be positive to be sus- 
tainable from a livelihood point of view. Here, the previous point applies as well. Demonstrating with quantitative procedures that striving for sustainable development does not necessarily imply loss of income, even possibly increasing incomes in the short, medium or long term, is crucial because in the information age words by themselves will not convince anyone. In one case, including an economist in the team allowed important conclusions as to farmers' income in a systems analysis of dairy systems in the Netherlands (Dolman et al., 2014). Specific examples are needed, also considering the important issue of land ownership and tenure. Land owners are traditionally more inclined to invest in their property, while tenants are more focused on short-term benefits (Teshome et al., 2014; Marques et al., 2015). But environmentally friendly practices may even pay off in the short run, and this will also be convincing for tenants. The simple and obvious statement that "land" has a price, while "soil" does not, has major implications when debating soil contributions to sustainable development because items that cannot be expressed in monetary terms tend to lose attention when, as so often, financial aspects dominate the debate.

The third and last level of constraint is the policy barriers. Politicians in democratic systems in the information age tend to be risk-averse and focused on activities that can generate favourable media exposure to their voters in the short term (Bouma and Montanarella, 2016). They are constantly approached by lobbyists, and choosing potential "winners" appears to become ever more important. So far, soil issues have not played a significant role in such strategic deliberations. Major policy changes all too often result from disasters, and a major problem for soil science is the fact that soil degradation is a creeping phenomenon that does not attract media attention. Of course, mudflows and flooding are often associated with poor soil management in upslope watersheds, but this link is not always well communicated. In general, policy aspects manifest themselves at three levels: strategic, tactical and operational. Providing examples of successful projects, as discussed above, can help to enable politicians to make sustainable decisions, but the effect is bound to be limited as ideological standpoints do not need to rely on evidence. Still, it is important to at least try to speak the language of the policy arena. That is why attention was paid in discussions above to the policy cycle and to the DPSIR procedure. More promising in the information age are bottom-up actions of engaged stakeholders who are the voters that ultimately, at least in democracies, determine the fate of any politician. Soil scientists would be well advised to connect with NGOs and local initiatives that focus on sustainable development. Moreover, measures to reduce soil degradation are usually expensive and do not provide revenues immediately. Legislation for soil protection is therefore unpopular. Finally, the assessment and monitoring of soil quality is tedious as soil is heterogeneous in nature, and good monitoring methodologies are expensive or even non-existent. Continued attention for streamlining and developing innovative procedures is therefore needed, and the introduction of remote and proximal sensors may make important contributions in this context (Viscarra Rossel et al., 2010; Stoorvogel et al., 2015). In addition, it is important to enhance the availability of existing soil data for policy makers (Montanarella et al., 2016).

In conclusion, political barriers are severe but they can be overcome by developing convincing examples of landrelated sustainable development that voters can present and lobby for when engaging with politicians.

\subsection{Implications for the soil science discipline}

Soil scientists are becoming aware of their central role in initiating the systems approach necessary to combine aspects of different disciplines. Although many soil science projects are still highly disciplinary, examples are increasingly available to demonstrate successful results of inter- and transdisciplinary studies (e.g. Mota et al., 1996; Schröter et al., 2005; Tittonell et al., 2010; Dolman et al., 2014; de Vries et al., 2015; Berendse et al., 2015; Keesstra et al., 2012; Brevik et al., 2015; Torn et al., 2015). Such studies advance the knowledge base by including basic research, which is crucial to maintain a vital scientific discourse and develop novel solutions for societal challenges. Using methodologies developed and established in other disciplines can solve problems in other fields that have been lingering for decades.

But within soil science itself, work remains to be done, focusing on the following question: how should action be taken? An example is the comparability of methods and data. Measured data are usually assumed to represent the truth and are used for calibrating models and executing scenario analysis for decision making. However, the value of data is determined by the experimental setup, the sampling scheme and the measurement technique itself. Too often data are used without considering these constraints. An example is the widespread, indiscriminate use of pedo-transfer functions (Romano, 2004; Pringle et al., 2007). To be able to transfer data from one research project to the next, it is important to validate and harmonize technologies and methodologies as well as standardizing information to achieve sound science that allows reliable translation into relevant information for stakeholders.

The key to establish more effective inter- and transdisciplinary, holistic research is to communicate to stakeholders, business leaders and policy makers and to reach out and invite scientists from other disciplines to participate. The climate change research community has successfully achieved communication of scientific results with stakeholders and policy makers. This requires special abilities that are not being taught in current scientific education. We should educate "knowledge brokers" that have the ability to inject the right type of knowledge to the right person at the right time and place. One important constraint for new developments is the way science is funded at this time, stimulating competition rather than collaboration. 


\subsection{Is there a key message from soil science?}

The public needs to become more engaged with soils because changes to sustainable forms of land use are only possible when children, farmers, citizens, teachers, business leaders and policy makers become more aware of the central function of soils in our society. This calls not only for relatively simple messages but also for symbols and narratives that appeal to people. Greenhouse gases are a universally known symbol for climate change and so are polar bears to illustrate warming of the ice caps. Economists use gross national product (GNP) and particularly its growth percentage as a well-known symbol of material well-being that is embraced by the political arena. Pictures of hungry children illustrate the concept of food security.

For soils, the organic matter content of mineral soils could be a suitable symbol for soil quality as it positively affects most soil functions. This applies to cultivated soil and grass lands with a "living carbon pool" and not to accumulations of organic matter because there is no biological activity. Higher organic matter contents in a given soil increases its adsorptive capacity for nutrients and water and improves soil structure and its stability. Soil organic carbon is also associated with a higher biodiversity that is a proper symbol for a "living soil", and, last but not least, increased soil organic carbon stocks will mitigate atmospheric $\mathrm{CO}_{2}$ concentrations. Of course, this has been known for a long time by soil scientists, but identifying a suitable symbol for soils cannot be based on knowledge alone but needs to be easily accessible and to be able to somehow trigger the imagination of outsiders. From a practical point of view, soil organic matter contents are relatively easy to measure, most recently also by handheld proximal sensors allowing real-time monitoring of changes of soil organic carbon in time and space (e.g. Viscarra Rossel et al., 2010; Stoorvogel et al., 2015). Given the possible role of soils in climate mitigation, and their role in underpinning sustainable development, the lasting legacy of the International Year of Soils in 2015 should be to put soils at the centre of policy supporting environmental protection, sustainable development, and the delivery of climate mitigation (Smith et al., 2015). An important challenge, and essential contribution from the scientific community, will be to provide the guidance and expertise needed to effectuate sustainable carbon sequestration. Given the complex interplay of (local) factors that govern the carbon sequestration (potential) in the various soils and ecosystems of our planet, rigorous scientific underpinning is needed to devise tailormade location-specific soil management schemes aimed at optimizing carbon sequestration whilst acknowledging other important ecosystem services. In addition, there is a need for cheap and reliable monitoring of (trends in) soil organic carbon content.

\section{Recommendations}

- Embrace the SDGs: the UN SDGs provide a widely recognized societal framework that allows soil science to demonstrate its relevance for realizing a sustainable society by 2030 .

- Show the specific value of soil science: research should explicitly show how using modern soil information can improve the results of inter- and transdisciplinary studies on SDGs related to food security, water scarcity, climate change, biodiversity loss and health threats. Implications for society should be communicated in terms that appeal to stakeholders, citizen at large and the policy arena. Well-documented and specific examples ("lighthouses") are most effective.

- Take leadership in overarching systems-analyses of ecosystems: given the integrative nature of soils, soil scientists are in a unique position to initiate and guide a comprehensive systems analysis of ecosystems, integrating land-related SDGs.

- Raise awareness of soil organic matter as a key attribute of soils to illustrate its importance for soil functions and ecosystem services. Show how soil management can manipulate the organic matter content and quality of any given soil.

- Improve the transfer of knowledge: inter- and transdisciplinarity require effective communication of soil knowledge and expertise to outsiders with little knowledge about soils. Knowledge brokers with a soil background can play an important role here. They should be professionally selected and educated, emphasizing the need for data collection and sharing.

- Start at the basis: global citizens have access to an everincreasing volume of data on the internet, some of it relevant, much of it of dubious quality. As educational standards increase, global citizens will use this information to form opinions and make decisions. Our task is to insert our evidence-based knowledge in the opinionforming and decision-making process at the right time and place, and in the right way. This fits well within the citizen-science concept. Overall, educational programmes are needed at all levels, starting in primary schools, and with emphasis on practical, down-to-earth examples.

- Facilitate communication with the policy arena: frame research in terms that resonate with politicians in terms of the policy cycle or by considering drivers, pressures and responses affecting impacts of land use change. Approaching the policy arena through stakeholders and citizens may, however, be most effective in the information age. 
- Collaborate beyond the comfort zone: all this is only possible if researchers look over the hedge towards other disciplines, to the world at large and to the policy arena, reaching over to listen first, as a basis for genuine collaboration.

Edited by: P. Finke

\section{The Supplement related to this article is available online at doi:10.5194/soil-2-111-2016-supplement.}

Edited by: P. Finke

\section{References}

Adimassu, Z., Mekonnen, K., Yirga, C., and Kessler, A.: Effect of soil bunds on runoff, soil and nutrient losses, and crop yield in the central highlands of Ethiopia, Land Degrad. Dev., 25, 554-564, doi:10.1002/ldr.2182, 2014.

Althaus, C., Bridgman, P., and Davis, G.: The Australia Policy handbook, 4th Edn., Allen and Unwin, Sydney, Australia, 2007.

Araya, A., Stroosnijder, L., Habtu, S., Keesstra, S. D., Berhe, M., and Hadgu, K. M: Risk assessment by sowing date for barley (Hordeum vulgare) in northern Ethiopia, Agr. Forest Meteorol., 154, 30-37, 2012.

Arnaez, J., Lasanta, T., Errea, M. P., and Ortigosa, L.: Land abandonment, landscape evolution, and soil erosion in a Spanish Mediterranean mountain region: the case of Camero Viejo, Land Degrad. Dev., 22, 537-550, 2011.

Bardgett, R. D. and Van der Putten, W. H.: Soil biodiversity and ecosystem functioning, Nature, 515, 505-511, 2014.

Bardgett, R. D. and Wardle, D. A.: Aboveground-Belowground Linkages: Biotic Interactions, Ecosystem Processes, and Global Change, Oxford Series in Ecology and Evolution, Oxford University Press, 2010.

Baudron, F., Delmotte, S., Corbeels, M., Herrera, J. M., and Tittonell, P.: Multi-scale trade-off analysis of cereal residue use for livestock feeding vs. soil mulching in the Mid-Zambezi Valley, Zimbabwe, Agr. Syst., 134, 97-106, 2014.

Baum, R., Luh, J., and Bartram, J.: Sanitation: A Global Estimate of Sewerage Connections without Treatment and the Resulting Impact on MDG Progress, Environ. Sci. Technol., 47, 1994-2000, 2013.

Berendse, F., van Ruijven, J., Jongejans, E., and Keesstra, S.: Loss of plant species diversity reduces soil erosion resistance, Ecosystems, 18, 881-888, doi:10.1007/s10021-015-9869-6, 2015.

Blankinship, J. C., Niklaus, P., and Hungate, B. A.: A meta-analysis of responses of soil biota to global change, Oecologia, 165, 553$565,2011$.

Boogaard, A.: "Garden agriculture" and the nature of early farming in Europe and the Near East, World Archaeol., 37, 177-196, 2005.

Bonfante, A. and Bouma, J.: The role of soil series in quantitative Land Evaluation when expressing effects of climate change and crop breeding on future land use, Geoderma, 259-260, 187-195, 2015.
Bonney, R., Shirk, J. L., Phillips, T. B., Wiggins, A., Ballard, H. L., Miller-Rushing, A. J., and Parrish, J. K.: Next steps for citizen science, Science, 343, 1436-1437, 2014.

Bouma, J.: Engaging soil science in transdisciplinary research facing wicked problems in the information society, Soil Sci. Soc. Am. J., 79, 454-458, doi:10.2136/sssaj2014.11.0470, 2015a.

Bouma, J.: Reaching out from the Soil-Box in pursuit of soil security, J. Soil Sci. Plant Nutr., 61, 556-565, doi:10.1080/00380768.2015.1045403, 2015b.

Bouma, J. and Montanarella, L.: Facing policy challenges with inter- and transdisciplinary soil research focused on the SDG's, SOIL Discuss., doi:10.5194/soil-2016-2, in review, 2016.

Bouma, J., Stoorvogel, J. J., Quiroz, R., Staal, S., Herrero, M., Immerzeel, M., Roetter, R. P., van den Bosch, H., Sterk, G., Rabbinge R., and Chater, S.: Ecoregional Research for Development, Adv. Agronomy, 93, 257-311, 2007.

Bouma, J., de Vos, J. A., Sonneveld, M., Heuvelink, G., and Stoorvogel, J. J: The role of scientists in multiscale land use analysis: lessons learned from Dutch communities of practice, Adv. Agronomy, 97, 177-239, 2008.

Bouma, J., van Altvorst, A. C., Eweg, R., Smeets, P. J. A. M., and van Latesteijn, H. C.: The role of knowledge when studying innovation and the associated wicked sustainability problems in agriculture, Adv. Agronomy 113, 285-314, 2011.

Bouma, J., Broll, G., Crane, T. A., Dewitte, O., Gardi, C., Schulte, R., and Towers, W.: Soil information in support of policy making and awareness raising, Curr. Opin. Environ. Sustain., 4, 1-7, 2012.

Bouma, J., Kwakernaak, C., Bonfante, A., Stoorvogel, J. J., and Dekker, L. W.: Soil science input in Transdisciplinary projects in the Netherlands and Italy, Geoderma Regional, 5, 96-105, doi:10.1016/j.geodrs.2015.04.002, 2015.

Brevik, E. C. and Burgess, L. C. (Eds.): Soils and human health, CRC Press, Boca Raton, FL, 408 pp., 2012.

Brevik, E. C., Cerdà, A., Mataix-Solera, J., Pereg, L., Quinton, J. N., Six, J., and Van Oost, K.: The interdisciplinary nature of SOIL, SOIL, 1, 117-129, doi:10.5194/soil-1-117-2015, 2015.

Bruelle, G., Naudin, K., Scopel, E., Domas, R., Rabeharisoa, L., and Tittonell, P. A.: Short-to mid-term impact of conservation agriculture on yield variability of upland rice: Evidence from farmer's fields in Madagascar, Exp. Agr., 51, 66-84, 2015.

Castellanos-Navarrete, A., Tittonell, P. A., Rufino, M. C., and Giller, K. E.: Feeding, crop residue and manure management for integrated soil fertility management - A case study from Kenya, Agr. Syst., 134, 24-35, 2015.

Cerdà, A. and Lasanta, T.: Long-term erosional responses after fire in the Central Spanish Pyrenees: 1. Water and sediment yield, Catena, 60, 59-80, 2005.

Cerdà, A., Flanagan, D. C., le Bissonnais, Y., and Boardman, J.: Soil erosion and agriculture, Soil Tillage Res., 106, 107-108, 2009a.

Cerdà, A., Morera, A. G., and Bodí, M. B.: Soil and water losses from new citrus orchards growing on sloped soils in the western Mediterranean basin, Earth Surf. Proc. Land., 34, 1822-1830, doi:10.1002/esp.1889, 2009b.

Cerdà, A., González-Pelayo, O., Jordan, A., Pereira, P., Novara, A., Brevik, E. C., Prosdocimi, M., Mahmoodabadi, M., Shahid, B., Keesstra, S. D., García Orenes, F., and Ritsema, C.: The use of barley straw residues to avoid high erosion and runoff rates on persimmon plantations in Eastern Spain under low frequency - 
high magnitude simulated rainfall events, Soil Res., 54, 54-165, doi:10.1071/SR15092, 2016.

Corral-Nunez, G., Opazo-Salazar, D., GebreSamuel, G., Tittonell, P., Gebretsadik, A., Gebremeskel, Y., Tesfay, G., and van Beek, C. L.: Soil organic matter in Northern Ethiopia, current level and predicted trend: a study case of two villages in Tigray, Soil Use Manage., 30, 487-495, 2014.

Costa, J. L., Aparicio, V., and Cerdà, A.: Soil physical quality changes under different management systems after 10 years in the Argentine humid pampa, Solid Earth, 6, 361-371, doi:10.5194/se-6-361-2015, 2015.

Cox, P. M., Betts, R. A., Jones, C. D., Spall, S. A., and Totterdell, I. J.: Acceleration of global warming due to carbon-cycle feedbacks in a coupled climate model, Nature, 408, 184-187, 2000.

Deasy, C., Quinton, J. N., Silgram, M., Bailey, A. P., Jackson, B., and Stevens, C. J.: Mitigation Options for Sediment and Phosphorus Loss from Winter-sown Arable Crops, J. Environ. Qual., 38, 2121-2130, 2009.

De Groot, P., Wilson, M. A., and Boumans, R. M. J.: A typology for the classification and valuation of ecosystem functions, goods and services, Ecol. Econ., 41, 393-408, 2002.

De Ponti, T., Rijk, B., and Van Ittersum, M. K.: The crop yield gap between organic and conventional agriculture, Agr. Syst., 108, $1-9,2012$.

de Vries, F. T., Liiri, M. E., Bjornlund, L., Bowker, M. A., Christensen, S., Setala, H. M., and Bardgett, R. D.: Land use alters the resistance and resilience of soil food webs to drought, Nat. Clim. Change, 2, 276-280, 2012.

de Vries, W., Kros, J., Dolman, M. A., Vellinga, T. H. V., de Boer, H. C., Sonneveld, M. P. W., and Bouma, J.: Environmental impacts of innovative dairy farming systems aiming at improved internal nutrient cycling: a multi-scale assessment, Sci. Total Environ., 536, 432-442, 2015

Diarisso, T., Corbeels, M., Andrieu, N., Djamen, P., and Tittonell, P.: Biomass transfers and nutrient budgets of the agro-pastoral systems in a village territory in south-western Burkina Faso, Nutr. Cycl. Agroecosys., 101, 295-315, 2015.

Döll, P., Müller Schmied, H., Schuh, C., Portmann, F. T., and Eicker, A.: Global-scale assessment of groundwater depletion and related groundwater abstractions: Combining hydrological modeling with information from well observations and GRACE satellites, Water Resour. Res., 50, 5698-5720, 2014.

Dolman, M. A., Sonneveld, M. P. W., Mollenhorst, H., and de Boer, I. J. M.: Benchmarking the economic, environmental and societal performance of Dutch dairy farms aiming at internal recycling of nutrients, J. Clean. Prod., 73, 245-252, doi:10.1016/j.jclepro.2014.02.043, 2014.

Dominati, E., Mackay, A., Green, S., and Patterson, M.: A soilchange based methodology for the quantification and valuation of ecosystem services from agro- ecosystems: A case study of pastural agriculture in New Zealand, Ecol. Econ., 100, 119-129, 2014.

Ettema, C. H. and Wardle, D. A.: Spatial soil ecology, Trends Ecol. Evol., 17, 177-183, 2002.

European Commission (EC): Communication from the Commission to the Council, the European Parliament, the European Economic and Social Committee and the Committee of the Regions, Thematic Strategy for Soil Protection, COM 231 Final, Brussels, 2006.
Ferwerda, W. H.: Four Returns, Three Zones, 20 Years: a systemic and practical approach to scale up landscape restoration by businesses and investors to create a restoration industry, in: Land Restoration: Reclaiming Landscapes for a Sustainable Future, edited by: Chabay, I., Frick, C. M., and Helgeson, J. F., Elseviers Science, 560 pp., 2015.

Fialho, R. C. and Zinn, Y. L.: Changes in soil organic carbon under Eucalyptus plantations in Brazil: A comparative analysis, Land Degrad. Dev., 25, 428-437, doi:10.1002/ldr.2158, 2014.

Franz, E., Semenov, A. V., Termorshuizen, A. J., de Vos, O. J., Bokhorst, J. G., and van Bruggen, A. H. C.: Manureamended soil characteristics affecting the survival of E. coli O157:H7 in 36 Dutch soils, Environ. Microbiol., 10, 313-327, doi:10.1111/j.1462-2920.2007.01453.x, 2008.

Gardi, C., Jeffery, S., and Saltelli, A.: An estimate of potential threats levels to soil biodiversity in EU, Glob. Change Biol., 19, 1538-1548, 2013.

Gottschalk, P., Smith, J. U., Wattenbach, M., Bellarby, J., Stehfest, E., Arnell, N., Osborn, T. J., Jones, C., and Smith, P.: How will organic carbon stocks in mineral soils evolve under future climate? Global projections using RothC for a range of climate change scenarios, Biogeosciences, 9, 3151-3171, doi:10.5194/bg-9-3151-2012, 2012.

Gu, G., Cevallos-Cevallos, J. M., Vallad, G. E., and van Bruggen, A. H.: Organically managed soils reduce internal colonization of tomato plants by Salmonella enterica serovar Typhimurium, Phytopathology, 103, 381-388, doi:10.1094/PHYTO-04-12-0072FI, 2013.

Hartkoorn, R. C., Sala, C., Neres, J., Pojer, F., Magnet, S., Mukherjee, R., and Cole, S. T.: Towards a new tuberculosis drug: pyridomycin-nature's isoniazid, EMBO molecular medicine, 4, 1032-1042, 2012.

Hoekstra, A. Y. and Mekonnen, M. M.: The water footprint of humanity, P. Natl. Acad. Sci. USA, 109, 3232-3237, 2012.

Hooper, D. U., Chapin Iii, F., Ewel, J., Hector, A., Inchausti, P., Lavorel, S., Lawton, J., Lodge, D., Loreau, M., and Naeem, S.: Effects of biodiversity on ecosystem functioning: a consensus of current knowledge, Ecol. Monographs, 75, 3-35, 2005.

Jansen, B., Kalbitz, K., and McDowell, W. H.: Dissolved Organic Matter: Linking Soils and Aquatic Systems, Vadose Zone J., 13, doi:10.2136/vzj2014.05.0051, 2014.

Joosten, H., Sirin, A., Couwenberg, J., Laine, J., and Smith, P.: The role of peatlands in climate regulation, in: Peatland restoration and ecosystem services, edited by: Bonn, A., Allott, T., Evans, M., Joosten, H., and Stoneman, R., Cambridge University Press, Cambridge, UK, 2015.

In't Veld, R. J. (Ed.): Knowledge Democracy, Consequences for science, politics and media, Springer Verlag, Berlin, Heidelberg, 2010.

Keesstra, S. D., van Dam, O., Verstraeten, G., and van Huissteden, J.: Changing sediment generation due to natural reforestation in the Dragonja catchment, SW Slovenia, Catena, 78, 60-71, 2009.

Keesstra, S. D., Geissen, V., van Schaik, L., Mosse, K., and Piiranen, S.: Soil as a filter for groundwater quality, Curr. Opin. Environ. Sustain., 4, 507-516, doi:10.1016/j.cosust.2012.10.007, 2012.

Keesstra, S. D., Pereira, P., Novara, A., Brevik, E. C., AzorinMolina, C., Parras-Alcántara, L., Jordán, A., and Cerdà, A.: Ef- 
fects of soil management techniques on soil water erosion in apricot orchards, Sci. Total Environ., in press, 2016.

Lal, R.: Soil carbon sequestration impacts on global climate change and food security, Science, 304, 1623-1627, 2004.

Lasanta, T., Vicente Serrano, S. M., and Cuadrat, J. M.: Mountain mediterranean landscape evolution caused by the abandonment of traditional primary activities: a study of the Spanish Central Pyrenees, Appl. Geogr., 25, 47-65, 2005.

Laudicina, V. A., Novara, A., Barbera, V., Egli, M., and Badalucco, L.: Long-Term Tillage and Cropping System Effects on Chemical and Biochemical Characteristics of Soil Organic Matter in a Mediterranean Semiarid Environment, Land Degrad. Dev., 26, 45-53, doi:10.1002/ldr.2293, 2015.

Lesschen, J. P., Cammeraat, L. H., and Nieman, T.: Erosion and terrace failure due to agricultural land abandonment in a semiarid environment, Earth Surf. Proc. Land., 33, 1574-1584, 2008.

Ling, L. L., Schneider, T., Peoples, A. J., Spoering, A. L., Engels, I., Conlon, B. P., Müller, A., Schäberle, T. F., Hughes, D. E., Epstein, S., Jones, M., Lazarides, Steadman, V. A., Cohen, D. R., Felix, C. R., Fetterman, K. A., Millett, W. P., Nitti, A. J., Zullo, A. M., Chen, C., and Lewis, K.: A new antibiotic kills pathogens without detectable resistance, Nature, 517, 455459, doi:10.1038/nature14098, 2015.

Liu, S. C., Minton, N. P., Giaccia, A. J., and Brown, J. M.: Anticancer efficacy of systemically delivered anaerobic bacteria as gene therapy vectors targeting tumor hypoxia/necrosis, Gene therapy, 9, 291-296, 2002.

Lowry, C. A., Hollis, J. H., De Vries, A., Pan, B., Brunet, L. R., Hunt, J. R., and Lightman, S. L.: Identification of an immuneresponsive mesolimbocortical serotonergic system: potential role in regulation of emotional behaviour, Neuroscience, 146, 756772, 2007.

Marques, M. J., Bienes, R., Cuadrado, J., Ruiz-Colmenero, M., Barbero-Sierra, C., and Velasco, A.: Analysing Perceptions Attitudes and Responses of Winegrowers about Sustainable Land Management in Central Spain, Land Degrad. Dev., 26, 458-467, doi:10.1002/ldr.2355, 2015.

Mol, G. and Keesstra, S. D.: Editorial: "Soil science in a changing world”, Curr. Opin. Environ. Sustain., 4, 473-477, 2012.

Montanarella, L.: Agricultural policy: Govern our soils, Nature comments, 528, 32-33, doi:10.1038/528032a, 2015a.

Montanarella, L.: Govern our Soils, Nature, 528, 32-33, 2015 b.

Montanarella, L. and Lobos Alva, I.: Putting soils on the agenda: The Three Rio Conventions and the post-2015 Development Agenda, Curr. Opin. Environ. Sustain., 15, 41-48, 2015.

Montanarella, L., Pennock, D. J., McKenzie, N., Badraoui, M., Chude, V., Baptista, I., Mamo, T., Yemefack, M., Singh Aulakh, M., Yagi, K., Young Hong, S., Vijarnsorn, P., Zhang, G.-L., Arrouays, D., Black, H., Krasilnikov, P., Sobocká, J., Alegre, J., Henriquez, C. R., de Lourdes Mendonça-Santos, M., Taboada, M., Espinosa-Victoria, D., AlShankiti, A., AlaviPanah, S. K., Elsheikh, E. A. E. M., Hempel, J., Camps Arbestain, M., Nachtergaele, F., and Vargas, R.: World's soils are under threat, SOIL, 2, 79-82, doi:10.5194/soil-2-79-2016, 2016.

Mota, J. F., Peñas, J., Castro, H., Cabello, J., and Guirado, J. S.: Agricultural development vs biodiversity conservation: the Mediterranean semiarid vegetation in El Ejido (Almería, southeastern Spain), Biodivers. Conserv., 5, 1597-1617, 1996.
Müller, A. and Weigelt, J.: Governance for a Land Degradation Neutral World, IISD Land Policy and Practice Knowledge Database, 2013.

Musinguzi, P., Ebanyat, P., Tenywa, J. S., Basamba, T. A., Tenywa, M. M., and Mubiru, D.: Precision of farmer-based fertility ratings and soil organic carbon for crop production on a Ferralsol, Solid Earth, 6, 1063-1073, doi:10.5194/se-6-1063-2015, 2015.

Nezomba, H., Mtambanengwe, F., Tittonell, P., and Mapfumo, P.: Point of no return? Rehabilitating degraded soils for increased crop productivity on smallholder farms in eastern Zimbabwe, Geoderma, 239, 133-145, 2015.

Novara, A., Gristina, L., Guaitoli, F., Santoro, A., and Cerdà, A.: Managing soil nitrate with cover crops and buffer strips in Sicilian vineyards, Solid Earth, 4, 255-262, doi:10.5194/se-4-2552013, 2013.

Olang, L. O., Kundu, P. M., Ouma, G., and Fürst, J.: Impacts of land cover change scenarios on storm runoff generation: A basis for management of the Nyando Basin, Kenya, Land Degrad. Dev., 25, 267-277, doi:10.1002/ldr.2140, 2014.

Pretty, J. N., Toulmin, C., and Williams, S.: Sustainable intensification in African agriculture, Int. J. Agr. Sustain., 9, 5-24, 2011.

Pringle, M. J., Romano, N., Minasny, B., Chirico, G. B., and Lark, R. M.: Spatial evaluation of pedotransfer functions using wavelet analysis, J. Hydrol., 333, 182-198, 2007.

Ramirez, K. S., Döring, M., Eisenhauer, N., Gardi, C., Ladau, J., Leff, J. W., Lentendu, G., Lindo, Z., Rillig, M. C., Russell, D., Scheu, S., St. John, M. G., de Vries, F. T., Wubet, T., van der Putten, W. H., and Wall, D. H.: Toward a global platform for linking soil biodiversity data, Front. Ecol. Environ., 3, 91, doi:10.3389/fevo.2015.00091, 2015.

Robinson, D. A., Fraser, I., Dominati, E. J., Davídsdottir, B., Jónsson, J. O. G., Jones, L., Jones, S. B., Tuller, M., Lebron, I., Bristow, K. L., Souza, D. M., Banwart, S., and Clothier, B.: On the Value of Soil Resources in the Context of Natural Capital and Ecosystem Service Delivery, Soil Sci. Soc. Am. J., 78, 685-700, 2014.

Romano, N.: Spatial structure of PTF estimates, in: Development of Pedotransfer Functions in Soil Hydrology, edited by: Pachepsky, Y. A. and Rawls, W. J., Elsevier Science B.V., 295-319, ISBN: 0-444-51705-7, 2004.

Rook, G. A.: Regulation of the immune system by biodiversity from the natural environment: an ecosystem service essential to health, P. Natl. Acad. Sci. USA, 110, 18360-18367, 2013.

Roy, M. and McDonald, L. M.: Metal uptake in plants and health risk assessments in metal-contaminated smelter soils, Land Degrad. Dev., 26, 785-792, doi:10.1002/ldr.2237, 2013.

Rufino, M. C., Tittonell, P., Reidsma, P., Lopez-Ridaura, S., Hengsdijk, H., Giller, K. E., and Verhagen, A.: Characterisation of N flows and $\mathrm{N}$ cycling in smallholder crop-livestock systems in the highlands of East and southern Africa using network analysis, Nutr. Cycl. Agroecosys., 313, 19-37, 2009.

Sacristán, D., Peñarroya, B., and Recatalá, L.: Increasing the Knowledge on the Management of $\mathrm{Cu}$-Contaminated Agricultural Soils by Cropping Tomato (Solanum Lycopersicum L.), Land Degrad. Dev., 26, 587-595, doi:10.1002/ldr.2319, 2015.

Sanchez, P., Palm, C., Sachs, J., Denning, G., Flor, R., Harawa, R., Jama, B., Kiflemariam, T., Konecky, B., Kozar, R., Lelerai, E., Malik, A., Modi, V., Mutuo, P., Niang, A., Okoth, H., Place, F., Sachs, S. E., Said, A., Siriri, D., Teklehaimanot, 
A., Wang, K., Wangila, J., and Zamba, C.: The African Millennium Villages, P. Natl. Acad. Sci. USA, 104, 16775-16780, doi:10.1073/pnas.0700423104, 2007.

Schmidt, M. W. I., Torn, M. S., Dittmar, T., Guggenberger, G., Janssens, I. A., Kleber, M., Kögel-Knabner, I., Lehmann, J., Manning, D. A. C., Nannipieri, P., Rasse, D. P., Weiner, S., and Trumbore, S. E.: Persistence of soil organic matter as an ecosystem property, Nature, 478, 49-56, 2011.

Schröter, D., Cramer, W., Leemans, R., Prentice, I. C., Araújo, M. B., Arnell, N. W., Bondeau, A., Bugmann, H., Carter, T., Garcia, C. A., de la Vega-Leinert, A. C., Erhard, M., Ewert, F., Glendining, M., House, J. I., Kankaanpää, S., Klein, R. J. T., Lavorel, S., Lindner, M., Metzger, M. J., Meyer, J., Mitchell, T., Reginster, I., Rounsevell, M., Sabaté, S., Sitch, S., Smith, B., Smith, J. U., Smith, P., Sykes, M. T., Thonicke, K., Thuiller, W., Tuck, G., Zaehle, S., and Zierl, B.: Ecosystem service supply and human vulnerability to global change in Europe, Science, 310, 1333-1337, 2005.

Schwilch, G., Hessel, R., and Verzandvoort, S. (Eds.): Desire for Greener Land, Options for sustainable land management in drylands, University of Bern-CDE, Switserland; Alterra, ISRIC, World Soil Information and CTA, Technical Center for Agricultural and Rural Cooperation, all in Wageningen, the Netherlands, 2012.

Selinus, O. (Ed.): Essentials of Medical Geology, Revised Edition, Springer, 2013.

Siebert, S. and Döll, P.: Quantifying blue and green virtual water contents in global crop production as well as potential production losses without irrigation, J. Hydrol., 384, 198-217, 2010.

Siebert, S., Kummu, M., Porkka, M., Döll, P., Ramankutty, N., and Scanlon, B. R.: A global data set of the extent of irrigated land from 1900 to 2005, Hydrol. Earth Syst. Sci., 19, 1521-1545, doi:10.5194/hess-19-1521-2015, 2015.

Six, J., Feller, C., Denef, K., Ogle, S. M., Sa, J. C. D. M., and Albrecht, A.: Soil organic matter, biota and aggregation in temperate and tropical soils - Effects of no-tillage, Agronomie, 22, 755775,2002

Shi, Y., Zhao, X., Gao, X., Zhang, S., and Wu, P.: The Effects of Long-term Fertiliser Applications on Soil Organic Carbon and Hydraulic Properties of a Loess Soil in China, Land Degrad. Dev., 27, 60-67, doi:10.1002/ldr.2391, 2015.

Skondras, N. and Karavitis, C.: Evaluation and Comparison of DPSIR Framework and the Combined SWOT - DPSIR Analysis (CSDA), Approach: Towards Embracing Complexity, 2015.

Smith, P.: Soils as carbon sinks - the global context, Soil Use Manage., 20, 212-218, 2004.

Smith, P.: Soils and climate change, Curr. Opin. Environ. Sustain., 4, 539-544, doi:10.1016/j.cosust.2012.06.005, 2012.

Smith, P., Fang, C., Dawson, J. J. C., and Moncreiff, J. B.: Impact of global warming on soil organic carbon, Adv. Agronomy, 97, 1-43, 2008a.

Smith, P., Martino, D., Cai, Z., Gwary, D., Janzen, H. H., Kumar, P., McCarl, B., Ogle, S., O’Mara, F., Rice, C., Scholes, R.J., Sirotenko, O., Howden, M., McAllister, T., Pan, G., Romanenkov, V., Schneider, U., Towprayoon, S., Wattenbach, M., and Smith, J. U.: Greenhouse gas mitigation in agriculture, Philos. T. Roy. Soc. B, 363, 789-813, doi:10.1098/rstb.2007.2184, 2008b.

Smith, P., House, J. I., Bustamante, M., Sobocká, J., Harper, R., Pan, G., West, P. C., Clark, J. M., Adhya, T., Rumpel, C., Paustian, K.,
Kuikman, P., Cotrufo, M. F., Elliott, J. A., McDowell, R., Griffiths, R. I., Asakawa, S., Bondeau, A., Jain, A. K., Meersmans, J., and Pugh, T. A. M.: Global change pressures on soils from land use and management, Glob. Change Biol., 537-586, 2015.

Stanchi, S., Freppaz, M., Agnelli, A., Reinsch, T., and Zanini, E.: Properties, best management practices and conservation of terraced soils in Southern Europe (from Mediterranean areas to the Alps): a review, Quatern. Int., 265, 90-100, 2012.

Stoorvogel, J. J., Kooistra, L., and Bouma, J.: Managing soil variability at different spatial scales as a basis for precision agriculture, Chapter 2, in: Soil Specific Farming: Precision Agriculture, Advances in Soil Science, edited by: Lal, R. and Stewart, B. A., CRC Press, Taylor Francis Group. Boca Raton, FL, USA, 37-73, 2015.

Teshome, A., de Graaff, J., Ritsema, C., and Kassie, M.: Farmers' perceptions about the influence of land quality, land fragmentation and tenure systems on sustainable land management in the north western ethiopian highlands, Land Degrad. Dev., doi:10.1002/ldr.2298, online first, 2014.

Tittonell, P.: Livelihood strategies, resilience and transformability in African agroecosystems, Agr. Syst., 126, 3-14, 2014.

Tittonell, P. and Giller, K. E.: When yield gaps are poverty traps: The paradigm of ecological intensification in African smallholder agriculture, Field Crop Res., 143, 76-90, 2013.

Tittonell, P., Vanlauwe, B., Corbeels, M., and Giller, K. E.: Yield gaps, nutrient use efficiencies and responses to fertilisers by maize across heterogeneous smallholder farms in western Kenya, Plant Soil, 313, 19-37, 2008.

Tittonell, P., Muriuki, A. W., Shepherd, K. D., Mugendi, D., Kaizzi, K. C., Okeyo, J., Verchot, L., Coe, R., and Vanlauwe, B.: The diversity of rural livelihoods and their influence on soil fertility in agricultural systems of East Africa - A typology of smallholder farms, Agr. Syst., 103, 83-97, 2010.

Torn, M. S., Chabbi, A., Crill, P., Hanson, P. J., Janssens, I. A., Luo, Y., Pries, C. H., Rumpel, C., Schmidt, M. W. I., Six, J., Schrumpf, M., and Zhu, B.: A call for international soil experiment networks for studying, predicting, and managing global change impacts, SOIL, 1, 575-582, doi:10.5194/soil-1-575-2015, 2015.

Thomson-Klein, J., Grossenbacher-Mansuy, W., Häberli, R., Bill, A., Scholz, R. W., and Welti, M.: Transdisciplinarity: joint problem solving among science, technology and society, An effective way for manageing complexity, Birkhauer Publ. Cie Basel, 2001.

Thornton, P. T., Ericksen, P. J., Herrero, M., and Challinor, A. J.: Climate variability and vulnerability to climate change: a review, Glob. Change Biol., 20, 3313-3328, doi:10.1111/gcb.12581, 2014.

Treseder, K. K.: Nitrogen additions and microbial biomass: A metaanalysis of ecosystem studies, Ecol. Lett., 11, 1111-1120, 2008.

Tsiafouli, M. A., Thébault, E., Sgardelis, S., De Ruiter, P. C., Van der Putten, W. H., Birkhofer, K., Hemerik, L., De Vries, F. T., Bardgett, R. D., Brady, M., Bjornlund, L., Bracht Jörgensen, H., Christensen, S., D’Hertfelt, T., Hotes, S., Hol, W. H. G., Frouz, J., Liiri, M., Mortimer, S. R., Setälä, H., Stary, J., Tzanopoulos, J., Uteseny, C., Wolters, V., and Hedlund, K.: Intensive agriculture reduces soil biodiversity across Europe, Glob. Change Biol., 21, 973-985, 2015.

Tonneijck, F. H., Jansen, B., Nierop, K. G. J., Verstraten, J. M., Sevink, J., and De Lange, L.: Carbon stocks and stabilization 
mechanisms in volcanic ash soils in natural Andean ecosystems of northern Ecuador, Eur. J. Soil Sci., 61, 392-405, 2010.

UNDESA, United Nations Department of Economic and Social Affairs: World population prospects: the 2012 revision, medium variant, available at: http://esa.un.org/unpd/wpp/unpp/ panel_population.htm, 2013.

Van Camp, L., Bujarrabal, B., Gentile, A. R., Jones, R. J. A., Montanarella, L., Olazabel, C., and Selvaradjou, S. K.: Reports of the Technical Working Groups established under the Thematic Strategy for Soil Protection, EUR 2131 '9EN/6, Office for the official publications of the European Commuinities, Luxembourg, 2004.

Van Grinsven, H. J. M., Erisman, J. W., de Vries, W., and Westhoek, H.: Potential of extensification of European agriculture for a more sustainable food system, focusing on nitrogen, Environmen. Res. Lett., 10, 025002, doi:10.1088/17489326/10/2/025002, 2015.

Viscarra Rossel, R. A., Mc Bratney, A., and Minashy, B. (Eds.): Proximal Soil Sensing, Prog. Soil Sci., Springer Verlag, 2010.

Vivant, A.-L., Garmyn, D., Maron, P.-A., Nowak, V., and Piveteau, P.: Microbial Diversity and Structure Are Drivers of the Biological Barrier Effect against Listeria monocytogenes in Soil, PLoS ONE, 8, e76991, doi:10.1371/journal.pone.0076991, 2013.

Vlek, P. L. G., Quang Bao, L., and Lulseged, T.: Land Decline in Land-rich Africa - A Creeping Disaster in the Making, CGIAR Science Council Secretariat, Rome, Italy, 63 pp., 2008. von Hertzen, L. and Haahtela, T.: Disconnection of man and the soil: reason for the asthma and atopy epidemic?, J. Allergy Clin. Immun., 117, 334-344, 2006.

Wall, D. H., Nielsen, U. N., and Six, J.: Soil biodiversity and human health, Nature, 528, 69-76, doi:10.1038/nature15744, 2015.

Wagg, C., Bender, S. F., Widmer, F., and van der Heijden, M. G. A.: Soil biodiversity and soil community composition determine ecosystem multifunctionality, P. Natl. Acad. Sci. USA, 111, 5266-5270, 2014.

Whitmore, A. P. and Schroeder, J. J.: Intercropping reduces nitrate leaching from under field crops without loss of yield: A modelling study, Eur. J. Agron., 27, 81-88, 2007.

WOCAT: Where the Land is Greener, Case studies and analysis of soil and water conservation initiatives worldwide, edited by: Liniger, H. and Critchley, W., CTA, FAO, UNEP and CDE publishers, 2007.

Young, I. M. and Crawford, J. W.: Interactions and self-organization in the soil-microbe complex, Science, 304, 1634-1637, 2004.

Zubkova, T. A., Krpachevsky, L. O., and Ashinov, Y. N.: Soil as a factor of human health, available at: http://cyberleninka. ru/article/n/pochva-kak-faktor-zdorovya-cheloveka (last access: 7 November 2015), 2013 (in Russian). 